\title{
CREATIVE THINKING TRAINING AS A MEANS OF DEVELOPMENT OF CONFLICT COMPETENCE OF A PROFESSIONAL
}

\begin{abstract}
Mergalyas M. Kashapov
Demidov Yaroslavl State University Yaroslavl

The psychological basis of creative thinking training as a means of development of conflict competence of a professional includes: in the first place, the knowledge of psychological nature of creative thinking of a professional; in the second place, recognition of above situational thinking as a leading quality in the structure of creative professional thinking; consideration of above situational thinking in the context of development of conflict competence of a professional, in the third place. In order to develop conflict competence, it is necessary to learn to get above the level of momentary requirements of a situation, to detect above situational problems, to set the goals, excessive from the point of view of the initial task. Professionals, thinking in terms of above situation, while analyzing a conflict situation, start to realize and actualize their own resources, which facilitates a creative way in problems resolving. It is the detection of above situational problems that forms the basis for creative thinking and is characterized by a set of key personal qualities necessary for his self-transformation as an agent.
\end{abstract}

Keywords: conflict competence, creative conflict resolution training, psychodiagnostics of metacognitive components of conflict competence, the analysis of cognitive characteristics of conflict interaction.

How is one to learn to behave constructively in conflict situations? How can one transform imminent defeat into a real victory? Such questions often arise, before beginners as well as skilled professionals. The necessity of creative thinking training in a conflict situation is caused by demands made by society and the state of experts professionalism. Creativity, coloring the process of professional decision-making, allows the person to carry out his activity more successfully. This makes the problem of purposeful creative thinking training as a means of enhancement of conflict competence of a professional on the basis of comprehension of the structure, dynamics, mechanisms and laws of creative process, so 
significant and urgent. However, the level of theoretical and methodological development of the problem in question does not correspond to its significance, which suggests the urgency of further research.

In this connection, the necessity of researching the problem connected with possibilities of revealing general and typical features of creative thinking of a professional (structure, levels, mechanisms, laws, functions, etc.), as well as specific manifestations of this process (stages, periods, phases), corresponding to a certain profile of the conflict situation being solved, is becoming rather urgent.

In modern psychological science fundamental general-theoretical problems of creative thinking psychology have been developed (A.V. Brushlinsky, J.P. Guilford, A.M. Matyushkin, Ya.A. Ponomarev, J. Renzulli, S.L. Rubinstein, R.J. Sternberg, O.K. Tikhomirov, E.P. Torrance, $M$. Wertheimer, and others); as well as the questions of the general and special mental abilities (V.N. Druzhinin, T.V. Galkina, V.A. Krutetsky, N.S. Leites, S.A. Mednick, V.D. Shadrikov, B.M. Teplov, M.I. Volovikova, A.N. Voronin, M.A. Wallach, and others). The research of effective means and methods of creativity development is of no less interest (G.S. Altshuller, O.S. Anisimov, Yu.D. Babaeva, D.B. Bogoyavlenskaya, V. Graf, I.I. Ilyasov, M.A. Kholodnaya, V.Ya. Lyaudis, A.M. Matyushkin, T.V. Ogorodova, D.V. Ushakov, D.V. Vilkeev, V.S. Yurkevich, and others); as well as methods of self-development of natural intellectual gifts (G.V. Burmenskaya, D. Chartier, Yu.Z. Gilbuh, E.V. Kotochigova, E. Loarer, V.M. Slutsky, E.D. Telegina); principles and specificity of age periodization of personality creative development (J.S. Bruner, V.V. Davydov, V.N. Druzhinin, E. Erikson, A.N. Gusev, M. Huteau, J. Piaget, J.C. Raven, E. Rubinoff, E.A. Sergienko, V.I. Slobodchikov, D.V. Ushakov, L.S. Vygotsky, and others); genesis of creative thinking in the context of professionalization (V.D. Shadrikov, B.B. Kosov, T.G. Kiseleva, E.V. Kotochigova, T.V. Ogorodova, Yu.V. Poshekhonova, G.D. Chistyakova, and others). However, research works, dedicated to the development of a creative-thinking professional, not infrequently facing conflict situations and open for discovery and adoption of new knowledge, are not particularly numerous (A.K. Markova, L.M. Mitina, V.I. Panov, N.V. Kuzmina, A.A. Rean, Yu.N. Kulyutkin, M.K. Tutushkina, V.A. Yakunin, and others). It is worth pointing out that in solving the problem of actualization and organization of effective creative professional thinking, empirical research prevails, it is based on the training approach and reports on 
inefficient operating conditions of creative professional thinking and the ways of their improvement. Analytical guideline of such investigations does not allow to take into account the real conditions of actualization of creative potential in professional work, it diminishes their scientific and practical value, and spurs further accumulation of isolated and non-generalized data. Few attempts at systematic research of the problem (O.S. Anisimov, A.V. Brushlinsky, D.V. Vilkeev, D.N. Zavalishina, T.V. Kornilova, Yu.N. Kulyutkin, A.M. Matyushkin, O.K. Tikhomirov, V.I. Slobodchikov, M.A. Kholodnaya, D.V. Ushakov, S.A. Tomchuk, O.A. Shlyapnikova) fail to cover the whole of problem area.

The ability to analyze one's own professional work is the basis for mastering the ways of creative conflict resolution. According to Yu.N. Yemelianov (1990, p. 166), the training aim here is to reduce the person's subjectivity in understanding of interpersonal situations. Therefore, it is impossible to study the specifics of professional creative thinking ignoring those psychological theories which regard creative thinking as the process aimed to go beyond a (set) concrete problem. For that matter, each scientific branch would suggest and substantiate its specific understanding of the structural unit of thinking.

Representatives of associative psychology (E. Mach, J.S. Mill, A. Bain, H. Spencer, T.-A. Ribot) suggest association as a structural unit of thinking. At Würzburg psychological school (O. Külpe, O. Selz, N. Ach, K. Marbe, A. Mayer, A. Messer, K. Bühler, H. Watt) a thinking unit was understood as an action. Gestalt-psychological treatment of thinking was developed as an opposition to associative psychology of thinking. M. Wertheimer, W. Köhler, K. Koffka, K. Lewin, K. Duncker and others, put out an integrity principle, as opposed to the associative principle of elements, as the main principle of perception (and then other mental processes as well). Gestalt-psychologists considered a gestalt as a thinking unit.

Within the psychoanalytic concept, the protective mechanism aimed at preservation of self-esteem, is identified as a thinking unit. K. Lashley contributed to development of advanced understanding of transcendence (self-transcendence). According to D. Magnusson, the perceptivecognitive-emotional self-evaluation of a person (including his reactions) joins a continuous stream of stimulus and events of a whole situation. Perception and cognitive evaluation of events and elements of situations is defined by the system of concepts and notion of a person about the 
world and himself. The interactional model is based on the statement that an individual is functioning and developing in a continuous process of interaction with the environment. In the course of this interaction the person acts as a subject of purposeful activity (L. Cronbach, D. Magnusson \& N. Endler, O'Connor). The cognitive approach (D. Norman, P. Lindsay, R. Lazarus, G. Kelly, J. Rotter, U. Neisser), the main progenitor of which was C.L. Hull, presents theoretical views on interaction of a person with his environment. A "new notion" or "scheme" was identified as a unit of the analysis of thinking. It is also possible to detect separate components of a situation as well as their interrelation in the course of resolution of a certain situation. Such researchers as J. Dewey, R. Solso, A. Weill-Fassina, P. Rabardel, D. Dubois, are interested in the nature of thinking processes whose actualization determines the cohesion of separate acts of thinking in strategy and tactics. As a result of their research the concept of thinking as a process of information handling and transformation has been formulated.

An attempt to systematize various cognitive theories and experimental data on the basis of the concept of mental representation is made by J.-F. Richard. He develops a productive approach, allowing to discard the scheme "stimulus - intermediate variable - reaction" and to unite stages of perceptive input, planning, executive action and result evaluation into a single model.

The system approach (I.V. Blauberg, V.N. Sadovsky, E.G. Yudin, V.A. Ganzen, B.F. Lomov, V.D. Shadrikov, A.V. Karpov) deserves special consideration, as it is focused on complex studying of an object as a complete system or its components in all leading connections. As a mental unit of thinking creativity Ya.A. Ponomarev suggests to consider the difference between the levels dominating at setting and solution of problems. D.B. Bogoyavlenskaya puts forward and substantiates intellectual activity as the creative thinking research unit.

Throughout recent decades psychological distinctions in development and behaviour of adults-professionals have been studied more differentially. Situationism as a new paradigm pinpoints the burning necessity to launch serious multidimensional studies of the situational models, which determine success of professional solutions (J. Barwise, V.N. Druzhinin, N.V. Grishina, B.I. Hasan, R.-K. Klaus, D. Magnusson, W. Mischel, R. Nisbett, L. Ross, J. Perry, L.A. Pervin, H. Raiffa, A.A. Verbitsky, Yu.N. Yemelyanov, and others). 
The process of thinking regulation (the active control over thinking processes, their planning, regulation and coordination) is studied intensively by representatives of metacognitive approach (Capeling, J. Keller, J. Flavell, A. Brown, W. Schneider, M. Pressley, and others). The possibility of purposeful formation of metacognitive skills, significant for successful interpersonal interaction, has recently become one of the most discussed issues. On the one hand, metacognitive abilities belong to the class of general abilities, they cannot be developed either by means of non-standard problems, or through teaching logic, programming, etc. (M. Pressley). On the other hand, D.N. Perkins and G. Salomon are trying to prove the alternative point of view that metacognitive skills can be formed on the basis of any field of knowledge in which the subject is competent enough. Moreover, from the point of view of the authors, the achievement of the highest level of professionalization in any field requires metacognitive control over the process of professional problems solution.

From this position a number of studies (M.A. Dirkes, G. Schraw, D.N. Perkins and G. Salomon, S.G. Paris and P. Winograd, and others), united by the idea that metacognitive strategies can be purposefully developed or worked out, appear to be of primary importance. In its turn, purposeful relying on your own metacognitive processes increases the efficiency of the solution of educational and professional problem situations (J. Borkowski, A.L. Brown, J.H. Flavell, R.H. Kluwe, A.V. Karpov, M.A. Kholodnaya, Yu.V. Poshekhonova, P. Biryukov, and others).

In this connection, creative thinking training as a means of increasing conflict competence of the professional is becoming a rather relevant issue. Nowadays the concept of «conflict competence» holds a special place in philosophical, sociological and psychological sciences. In addition, an increasing interest in study of various aspects and forms of conflict competence is constantly sustained. However, despite researches of social conflicts available in psychological science (Park \& Antonioni, 2007; De Dreu \& Nijstad, 2008; Wood \& Bell, 2008; Kaushal \& Kwantes, 2006; Rose, Shoham, Neill, \& Ruvio, 2007; Funes, Lupiáñez, \& Humphreys, 2010; Parayitam \& Dooley, 2009; Welch \& Wilkinson, 2005; Rizkalla, Wertheim \& Hodgson, 2008; Morsella, Gray, Krieger, \& Bargh, 2009; Kelman, 2005) dedicated to consideration of the given phenomenon, conflict competence is yet to be thoroughly studied. Study of conflict competence influence on efficiency of communicative activity, as well as mechanisms and conditions for its realization, requires more de- 
tailed consideration. The problem of working out technologies enabling formation of the given competence of a person, as well as its efficiency evaluation, also becomes significant.

Thus, the carried out analysis allows to prove theoretically the necessity and reasonability of defining the problem as a unit of the professional thinking analysis - for it is the problem that carries the most essential properties and functions of professional thinking. At the same time, it is the foundation of professional thinking actualization under the conditions of creative conflict resolution. This analysis unit allows to investigate and purposefully develop professional thinking, accounting for peculiarities of expert thinking transformation in the course of his or her professionalization.

The objective of our research is to work out a psychological approach to the development of creative thinking as a means of increasing the conflict competence of a professional on the basis of revealing metacognitive features, psychological principles, mechanisms and laws of creative thinking functioning in a conflict situation. The goals included: 1 . Development and testing of techniques employed to diagnose metacognitive characteristics of the conflict competence of a person. 2. Working out educational programmes for development and improvement of the basic structural -functional characteristics fundamental for the conflict competence of a person.

The basic diagnostic ideas of the research were realized by means of the following techniques: 1. Scale of Metacognitive Knowledge and Metacognitive Activity Assessment (Yu.V. Skvortsova, M.M. Kashapov). 2. The Questionnaire for Measuring a Creative Person's Abilities (O.A. Shlyapnikova, M.M. Kashapov). 3. The test Polysemantic Words (T.V. Ogorodova, M.M. Kashapov). 4. Diagnostics of Situational / Above Situational Level of Pedagogical Thinking (T.G. Kiseleva, M.M. Kashapov). 5. The Assessment of Creative Thinking of Teachers of Preschool Institutions (E.V. Kotochigova, M.M. Kashapov). 6. Diagnostics of the Type of Reaction in a Conflict (M.M. Kashapov, T.G. Kiseleva). The given technique, unlike that of $\mathrm{K}$. Thomas's, allowing to define such ways of behaviour in a conflict as rivalry, adaptation, compromise, avoiding and cooperation, diagnoses three ways: aggression, avoidance, optimal conflict resolution.

The study of a role of metaknowledge carried out together with Yu.V. Poshekhonova in the context of conflict competence has shown that metaknowledge carries out a number of major functions defining 
on the whole the efficiency of conflict resolution. During the specially organized training of college lecturers (based on the metacognitive approach) it has been found out that the level of metacognitive activity influences the intensity of dynamics of transition from the situational level of professional pedagogical thinking to the above situational one. The differentiation of teachers, according to the level of intensity of metacognitive components they demonstrate, has defined a number of authentic distinctions. The teachers with high scores of self-assessment on Metacognitive Knowledge scale, are characterized by the general external locus of control, externality in the field of interpersonal relations, and, accordingly, those with low scores - by the internal locus of control. Comparison of results of teachers with extreme scores on the scale of Metacognitive Activity has revealed the following distinctions: teachers with high scores on the indicated scale perceive more factors, as stimulating their professional development, rather than teachers with the low scores; teachers with low metacognitive activity are characterized by pedantic, autocratic behaviour and, on the contrary, the sphere of interpersonal communication of teachers with high metacognitive activity is characterised by lower disposition to autocratic, dictatorial and pedantic behaviour. It has been established that teachers with high achievement motivation have high metacognitive activity. Teachers with high level of metacognitive activity are characterized by a higher level of professional pedagogical thinking (this level is closer to the above situational one, than that of teachers with low scores on this scale). The level of pedagogical thinking of lecturers of medical institutes is closer to the above situational one, than that of teachers of medical colleges. Teachers of medical colleges are characterized by a higher level of metacognitive activity, concentration and time management, compared with lecturers of a medical institute.

It had been revealed that each substructure being part of the structure of a conflict competence of a person has the hierarchy based on a correlation of genetic and social factors, influencing character formation. Each of the revealed substructures, in their turn, can be divided into other components, that is indicative of the distinctions in the degree of manifestation within one structure. The importance of each property in the general personality rating can be various, that is the contribution of this or that indicator to general efficiency of an activity in the conditions of a conflict interaction can be different. 
The efficient resolution of arising contradictions as nuclear formations of the conflict, depends on developed professional skills of seeing and comprehending the set of all conditions of a problem-conflict situation, as well as the awareness of one's own cognitive characteristics contributing to better cognition and conflict resolution. The special part in comprehension of a conflict situation is assigned to metaknowledge which is considered as the knowledge of one's own thinking processes and strategies, ability for conscious reflection, change and realization of actions based on this knowledge. Identifying a conflict problematical character as a unit of the psychological analysis of conflict competence structure and study of a procedural stage of activity have allowed to analyze conflict resolution from the point of view of the included metacognitive strategy. The detailed consideration of pedagogical decision-making has provided the possibility to assume and empirically reveal positive associations between structural level-based characteristics of professional pedagogical thinking and metacognitive features of an intellectual sphere of a person. In particular, metacognitive activity and level of professional pedagogical thinking have been positively correlated.

Generalization of empirical findings shows that taking into account principles of creative thinking facilitates the development of the general approach to research and development of creative professional thinking in a conflict situation. The substantial principles underlying the development of creative thinking may include the principles of system, action complementarity of situational and above situational factors, preventiveness, contextualization, multiplication.

1. The principle of system includes the following particular principles: optimality (achievement of the best result with the least input of time and effort); structural properties (structural order of components); functionality (definition of tasks for each component); integrity (joining elements into a single whole). The system approach to conflict resolution is characterized by technology of application of a dialectic method.

2. The principle of action complementarity of situational (providing variability of professional behaviour) and above situational (providing the higher level of comprehension and realization of professional work) factors is characterized by the fact that in most cases determining factors are above situational ones whereas situational factors play a modulator part (defining variability of display of above situational factors). However, the hierarchy of factors can vary. It is domination of the above situ- 
ational factor that determines the situation transformation to the event, at times absolutely changing structural components of conflict competence and the person as a whole.

3. The principle of preventiveness - the professional develops warning facilities of possible occupational deviations for each level of detection of problems in a situation development and finds ways for their elimination.

4. The context principle - upon detecting an above situational problem, the professional invariably keeps a context of integral activity (avoiding "disorientation"), resisting momentary requirements of production on the one hand, and influence of strong impulsive emotions, on the other.

5. The multiplication principle-consideration of a cognizable object from the opposite points of view, which promotes the unbiased approach to a conflict problem.

In our opinion, the number of procedural principles include: $1 . \mathrm{Vi}$ sion of interrelation of professional work components; revealing their problematic character (mismatch). 2. Search of various approaches (the more sets of consideration of the phenomenon in question there are, the more efficient creative thinking of a professional is). 3. Release from the rigid control of the patterns and stereotypes of thinking, acquired for years. 4. Use of the case (to reap the results of casual interactions of ideas). To subject oneself to the influence of stimulating situations. The conscious intertwining of various directions of cognitive activity allows to turn conflict situation conditions into the means of its resolution. 5. Finding, working out and realizing new ideas at work.

Taking these principles into account enables orientation to the removal of the problem and consideration of the conflict resolution a product of professional thinking. Establishment and removal of the problem on the above situational level are inseparably linked with the generalized way of action or method. The generalized objective of a professional activity, as well as the delayed character of the realized creative decisions, leads to the hierarchy of processes and the results of thinking. The ability to see, formulate the most important task accounting for long-term and short-term positive prospects proves especially important. It is in the ability to establish and resolve the above situational problem that constructibility and concreteness of thinking of the professional is expressed. Thanks to actualization of the above situational thinking type 
there is the constructive transformation of professional activity leading to one's self-perfection as the subject.

The basis for creative conflict resolution is the transition from intuitive perception of principles and laws, which regulate professional activity, to their cognition, comprehension, conscious accounting and application. Such approach makes a professional the master of the situation, instead of a slave to the circumstances, dragging behind events. The knowledge of laws opens up new horizons for creative search, keeps one from wandering in the dark, makes it possible to discover the right solutions of professional problems in a conflict situation, and to do it faster and with more confidence. Otherwise it leads to mediocrity and parochialism of thinking. Therefore, as it becomes obvious, it is particularly important to understand the practical side of creative activity laws and the ability to use it.

A necessary pattern of creative thinking, its initial moment, is created by arising problem. The knowledge of causes of mismatch, difficulties in psychological activity allows to work out preventive measures in due time, to achieve a higher degree of a problem solution expertise. Problem detection induces a search for the missing information, its analysis and synthesis. As for significant features of a problem situation it is possible to define the subject's need for the problem solution in a completely new way. The problem search generates the need for any internal regulatory schemes allowing to organize the cogitative actions more efficiently.

So, the comprehension by the teacher of the necessity of argumentation of his or her actions (and not only relating to the assessment), putting this necessity into action is indicative of transition of the teacher from situational to above situational thinking level. In the research made together with T.G. Kiseleva, it has been established that the mediated-individual way of decision-making is a link allowing situational-thinking (ST) teachers to achieve above situational level. It is lessening an authoritative position of ST teachers that enables to shake professional stereotypes, through changing demands into requests and wishes - to move to the compromise, and then on to cooperation. Such approach allows to extend the perceived and assessed boundaries of a situation, to treat pupils as subjects, instead of objects of a situation that, in turn, will lead to comprehension by the teacher not only of short-term, but also long-term prospects of his or her actions. 
Our further research (M.V. Bashkin, N.I. Dobina, Yu.N. Zhihareva, O.Yu. Zakharycheva, A.V. Kamaeva, E.V. Kotochigova, O.Yu. Rudakova, I.V. Serafimovich, O.V. Sumarokov, M.V. Kharchenko) has shown and proved that situational-above situational level of a conflict resolution of teachers is manifested in the perspective of a decision made. If teachers with an ST level of problem detection see only the nearest consequences, their decisions are directed at introduction of momentary changes; ability to see long-term prospect and effect of the actions and to make corresponding decisions signifies going beyond the situation, the achievement of the above situational level.

Situation-bound thinking shows up in ignoring, inattention to interaction between a teacher and a pupil. Examining actions of pupils as if under a microscope, noticing the slightest deviations in their behaviour, ST teachers do not analyze (or hardly ever analyze) their own actions. One-sidedness while considering a conflict situation by this group of teachers leads to a one-sided solution. From the point of view of these teachers the conflict initiator is the pupil, hence, the problem solution is connected with him or her. ST teachers are not inclined to assess their own actions and that leads to their absolutization. The standard used for assessment is the teacher himself. The analysis of subjective borders of an assessment range has shown that the most effective constructs in professional work of ST teachers are scales "obstinate - compliant," "independent - dependent," "strained - weakened" and "irritable - calm." SM teachers consider obstinacy as a negative personality trait impeding teaching. It is to obstinacy that SM teachers relate many conflict situations. Estimating the educational activity, this category of teachers use subjective estimation scales without clearly defined, observable indicators; and a generalized situation assessment prevents them from seeing the issues opposite to the general view. Thus, the negative assessment of children's activity prevents ST teachers from noticing positive moments in the educational activity, and a lack of marks argumentation aggravates the opposition and misunderstanding between an ST teacher and children. As a result, the teacher cannot count on long-term cooperation with children, therefore an SM teacher prefers authoritative methods of teaching and, as consequence, the teacher making attempts to change the present conflict situation, directs his or her efforts at changing the pupils' position, ignoring his or her own, at times inadequate, position and activity. 
As opposed to ST teachers, the other pole of a continuum is occupied by teachers with above situational thinking (AST) level, whose estimation activity is characterized by a deeper analysis of a conflict situation and particular attention to their own pedagogical activity. AST teachers are more tolerant to negative displays in the educational activity. As for implicit estimation scales, it should be noted, that operation constructs of the above teachers are the following scales: "active - passive," "resolute - irresolute," "energetic - languid," "assured - uncertain," "sincere - insincere," "self-supporting - lacking in initiative," "independent - dependent." AST teachers are distinguished by the ability to notice advantages in the negative and drawbacks in the correct decision or action that is the characteristic of comprehensive consideration of the object of estimation, diversity of thinking. The decision made on the basis of the carried out analysis has the mediated-group character balancing interests of both parties, therefore AST teachers direct their efforts not only at change of behaviour and studying of pupils, but they also revise their own actions. Such approach allows the teacher to see a conflict situation entirely, to plan the strategy, to predict consequences of the actions.

According to A. Einstein the person cannot solve a problem if he or she solves it at the same level at which it was comprehended. The ability to find out the above situational problematic character in a conflict situation links practical and theoretical thinking of the professional as there is a transition from a particular problem solution to detecting general laws and principles of the professional problem solution. For example, a boss passes from organizing the work of the subordinates to creating constructive conflicts developing the personality of his or her personnel. The above situational problematical content is semantically fuller, than the situational problematic content.

Hence, for designing creative ways of conflict resolutions it is important to learn to change the conflict structure deliberately by means of the following actions: a) conflict initiation (predicting the logic of development of lines of force of contradictions leading to collision, conflict); b) conflict scenario (the conflict problem is considered from different points of view); c) conflict direction (variability, diversity as the basis of expansion and deepening of the idea directed at problem solution); d) conflict conducting - the process of indirect control of a conflict (ability to distinguish a reason from a cause, to transform situation conditions into the means of its resolution). 
The ability to reveal above situational problematical character enables to comprehend and operate the cause and effect relations. Through a conglomeration of particular details a professional can see general tendencies, laws of development of cognizable phenomena. Problems are the regularity of independent thinking. A theoretical aspect of professional thinking includes the ability to use theoretical laws and principles, significant for practical activities. The individuality of this type of thinking is characterized by the fact that the general laws and theoretical principles become a personality property of a professional. The regularities of thinking of a professional get special nuances owing to his/her strengths and weaknesses. The professional who solves a problem relying on the strongest points of his personality as well as of the situation, manages the situation better than others.

What are the specifics of psychological laws of the creative problem solution of a professional?

We have empirically discovered the laws of comprehensive organization of professional thinking processes (Kashapov, 2000; 2003; 2006a). As it was predicted, they belong to the laws of the integrative type. They particularly include the following: 1 . The "lower" the level of professional thinking is, the bigger the role of processes and qualities of prompt processing of the information on situational characteristics is. 2. The "higher" the level is, the more important is the role of qualities of above situational perception and understanding of information, personal features of a subject; there is no significant and stable connection between the efficiency of professional solutions and characteristics of development of particular mental properties and personal qualities. 3. There is a significant and stable relationship between the efficiency of these decisions and the degree of their integration in the structure of creative thinking of a professional. 4. The optimality of professional solutions is defined not by independent way of influence of individual components of professional thinking, but, to a large extent, by the efficiency of their interaction which is determined by regularities as repetitive connections between the elements.

The relation between cognition and thinking is realized through their products, i.e. knowledge. In knowledge, the patterns of investigated objects are removed. The professional has to start processing a phenomenon of problem by means of logic, making use of consciously organized experience and personal categorial system, transforming the problem 
into a creative informative problem, that is, an intellectual problem. Consciously organized experience is already not enough for a cognitive problem solution, which causes the need for new knowledge which is acquired through an unconscious experience. A new knowledge is obtained, first of all, by means of an intuitive decision. The further logical processing of an intuitive effect transforms the new knowledge into a logical one which can be used for making new steps in a problem situation. Such transformation is but verbalization and formalization of an intuitively gained effect.

It has been established, in a joint research with M.V. Bashkin, that conflict competence includes three components: cognitive (presented by informational and creative elements); motivational (characterized by domination of achievement motivation in a person's behaviour); regulative (including emotional, volitional and reflexive elements). The above components form an integral structure of conflict competence non-additively. Conflict competence contributes to realization of preventive measures in interpersonal interaction, ensuring adequate recognition and constructive conflict resolution. Conflict competence functions are as follows: preventive, prognostic, constructive, reflexive and correctional.

In the course of interpersonal interaction at different study levels there is a change of the structural organization of conflict competence of a person. University students, in comparison with high school students, are more focused on the optimal type of reaction in a conflict. The given strategy of students' behaviour reveals the relation to the indicators of motivational and cognitive components of their conflict competence.

In the course of professionalization of a school teacher and an engineer different dynamics of their conflict competence structure are observed. In the course of a teacher's professionalization, the level of structure organization of the given competence rises, which is revealed in positive dynamics of its emotional element and is expressed in the rise of emotional self-control level. In the course of professionalization of an engineer, the level of structure organization of his/her conflict competence lowers. It results in changes of creative and emotional elements of conflict competence, in decrease of creativeness, inquisitiveness, and also in hyperemotivity and display of shyness.

The relation between the optimal type of reaction in a conflict and a correlation of qualities of a person in the structure of his/her conflict competence has been revealed. The reflexive element (i.e. subjective lo- 
cus of control), forming a part of a regulative component structure is fundamental in the structure of the above competence. Mechanisms of functional dynamism, reciprocity and psychological adequacy determine peculiar functioning features of the conflict competence structure of a person. Creative thinking plays the role of a determinant of an optimal type of reaction in a conflict.

On the one hand, the patterns of creative thinking are based on the general laws of thinking, but on the other hand, they have a peculiarity. The laws of thinking are the cause-effect relations determining a direction and efficiency of the thinking process. Creativity, according to the psychological pattern established by Ya.A. Ponomarev (1960), exists only along with the self-development of a person which is impossible without relying on self-regulation resources of a person. A creative person deviates from rigid standards more often, he / she is not afraid of any forms of behaviour, including the childish ones. It helps the person to take a more balanced view of the situation. Each person is a creator if he/she is actively engaged in self-development. The creative professional thinking pattern has its ups and downs. One and the same factor (for example, the assessment) can help or prevent the professional from developing his or her creative abilities. Therefore, the problem of psychological support of the professional, assisting with formation of fundamental qualities of his / her creative thinking has emerged.

For successful formation and effective functioning of creative thinking of a professional there appears to be a sufficient reason for considering its patterns. The knowledge of general laws of a conflict interaction promotes the improvement of relations with the people significant for the subject.

Mastering the generalized principles of creative thinking gives the professional a chance to see his / her activity as a whole, to understand the logic and pattern of its course, and the most important thing is to generate new ideas directed at its further perfection. The established and well-reasoned laws, mechanisms and principles of creative thinking of the professional have been used as a basic principle of the newly developed educational program Creative. In each of the seven stages of training there is a description of more than 25 intellectual qualities. All the qualities, studied and formed during the training, more than 180 in all, together form creative thinking of the professional. After consideration of a certain quality, test tasks, exercises, methods, "a discussion 
swing" and other educational psychotechnologies are offered to the participants.

The specific character of an educational program presupposes separate functions of a professional (research, self-actualizations, therapeutic, etc.) to be picked and developed into a special activity, so that subsequently, being reduced and automated they could be integrated into a complete pattern of work of a professional. Readiness to resolve a conflict problem means giving up attempts to prove that the opponent is not right, as nobody has monopoly for the truth. The essence of an educational program is aimed at preparation for the successful solution of conflict situations. For this purpose, professionals need to learn, understand and consider adequately the context of carried out activity in realization of the decisions.

Our experience in training experts and executives at professional skills brush-up courses, reveals that many professionals require further development, not so much theoretical (substantial-comprehending) thinking, but rather practical (substantial-reformative) thinking. According to students, they are good at their work, "know their business," but it is not enough for efficient professional work since in everyday work they face a number of creative problems which they are not quite fit to solve. The evaluation of the efficiency of an educational program was made according to the following criteria: adequacy, profitability, efficiency, creativity of professional thinking.

Thus, creative thinking training as a means of increasing the conflict competence of a professional is possible through solution of certain problems. On the one hand, through the organization of some external conditions (methodical maintenance, timely training, etc.), directed at the formation of a professional as an agent. On the other hand, through measures directed at personal development, satisfying requirements for increasing communicative, and primarily, conflict competence which would allow not only to set the goals and tasks professionally but also to choose effective, adequate to the goals set, above situational means, ways and methods of professional work performance. The process of creative solution of a conflict situation is characterized mostly by the above situational thinking vector.

The practical importance of the analysis of the creative solution of a conflict situation procedural part components includes the detection and substantiation of certain goals of vocational training. The applied 
value of working out the problems of conflict competence is explicitly expressed in two areas: 1) methods of research (the package of psychodiagnostic techniques has been developed); 2) self-improvement of qualities of the creative thinking problem solution, presented in the Creative program, aimed at the optimal solution of conflict situations.

The following can be seen as a means of increasing the conflict competence:

1. Teaching to work out algorithms necessary for designing creative ways of the conflict situation solution.

2. Increasing conflict competence as integrated personal quality. The conflict competence in the field of interpersonal relationship is a kind of communicative competence, which possesses its essential qualitative signs: the complexity of structural organization having the integrated character; the coherence with structural level-based characteristics of creative professional thinking.

\section{References}

Borkowski, J., Carr, M., \& Pressley, M. (1987). “Spontaneous” strategy use: Perspectives from metacognitive theory. Intelligence, 11, 61-75.

Brown, A.L. (1987). Metacognition, executive control, self-regulation, and other more mysterious mechanisms. In F.E. Weinert \& R.H. Kluwe (Eds.), Metacognition, motivation, and understanding (pp. 65-116). Hillsdale, NJ: Lawrence Erlbaum Associates.

Cary, M., \& Reder, L.M. (2002). Metacodnition in Strategy Selection. Giving Consciousness Too Much Credit. In P. Chambers, M. Izaute, \& P.-J. Marescaux (Eds.), Metacognition: Process, Function and Use (pp. 63-79). Boston: Kluwer.

De Dreu, C.K.W., \& Nijstad, B.A. (2008). Mental Set and Creative Thought in Social Conflict: Threat Rigidity Versus Motivated Focus. Journal of Personality and Social Psychology, 95 (3), 648-661.

Flavell, J.H. (1976). Metacognitive Aspects of Problem Solving. In L.B. Resnick (Ed.), The Nature of Intelligence (pp. 231-235). Hillsdale, N.Y.: Erlbaum.

Flavell, J.H. (1977). Cognitive development. Englewood Cliffs, NJ: Prentice-Hall.

Flavell, J.H. (1979). Metacognition and cognitive monitoring: A new area of cognitive-developmental inquiry. American Psychologist, 34, 906-911.

Funes, M.J., Lupiáñez, J, \& Humphreys, G. (2010). Analyzing the Generality of Conflict Adaptation Effects. Journal of Experimental Psychology: Human Perception and Performance, 36 (1), 147-161.

Kashapov, M.M. (2000). Psihologiâ pedagogičeskogo myšleniâa [Psychology of pedagogical thinking]. Saint Petersburg: Aletejâ. 
Kashapov, M.M. (Ed.). (2003). Psihologiâ professional'nogo pedagogičeskogo myšleniâ [Psychology of professional pedagogical thinking]. Moscow: IP RAS.

Kachapov, M. (2004). La mentalire pedagogigue comme la competence essentielee du professeur. In 7-e Biennale de léducation et de formation. Débats sur les recherches et les innovations. Résumés des contributions (pp. 185-186). Lyon: INRP-APRIEF.

Kashapov, M.M. (2006a). Soveršenstvovanie tvorčeskogo myšleniâ professionala [Perfection of creative thinking of the professional]. Moscow, Yaroslavl: MAPN.

Kashapov, M.M. (2006b). Psihologiâ tvorčeskogo myšleniâ professionala [Psychology of professional creative thinking]. Moscow: PER SE.

Kachapov, M. (2006c). Régularités et mécanismes de la mentaliré créatrice du professeur. In 8-e Biennale de léducation et de formation. Débats sur les recherches et les innovations. Résumés des contributions (pp. 174-175). Lyon: INRP-APRIEF.

Kashapov, M.M., \& Leybina, A.V. (2009). Motivation of Professional Creative Thinking. In Yu.P. Zinchenko \& V.F. Petrenko (Eds.), Psychology in Russia: State of the Art. Scientific Yearbook (pp. 585-602). Moscow: RPS.

Kachapov, M., \& Sokolova V. (2002). Entraînement vidéo comme méthode d'acguisition de l'expérience de conduite en conflits. In 6-e Biennale de l'éducation et de formation. Débats sur les recherches et les innovations. Résumés des contributions (pp. 230-231). Paris: APRIEF-INRP.

Kaushal, R., \& Kwantes, C.T. (2006). The role of culture and personality in choice of conflict management strategy. International Journal of Intercultural Relations, 30 (5), 579-603.

Kelman, H.C. (2005). Building trust among enemies: The central challenge for international conflict resolution. International Journal of Intercultural Relations, 29 (6), 639-650.

Kluwe, R.H. (1982). Cognitive knowledge and executive control: Metacognition. In D.R. Griffin (Ed.), Animal mind - human mind (pp. 201-224). New York: Springer.

Morsella, E., Gray, J.R., Krieger, S.C., \& Bargh, J.A. (2009). The Essence of Conscious Conflict: Subjective Effects of Sustaining Incompatible Intentions. Emotion, 9 (5), 717-728.

Parayitam, S., \& Dooley, R.S. (2009). The interplay between cognitive- and affective conflict and cognition- and affect-based trust in influencing decision outcomes. Journal of Business Research, 62 (8), 789-796.

Paris, S.G., \& Winograd, P. (1990). How metacognition can promote academic learning and instruction. In B.F. Jones \& L. Idol (Eds.), Dimensions of thinking and cognitive instruction (pp. 15-51). Hillsdale, NJ: Erlbaum.

Park, H., \& Antonioni, D. (2007). Personality, reciprocity, and strength of conflict resolution strategy. Journal of Research in Personality, 41 (1), 110-125.

Ponomarev, Ya.A. (1960). Psihologiâ tvorčeskogo myšleniâa [Psychology of Creative Thinking]. Moscow: Nauka. 
Rizkalla, L., Wertheim, E.H., \& Hodgson, L.K. (2008). The roles of emotion management and perspective taking in individuals' conflict management styles and disposition to forgive. Journal of Research in Personality, 42 (6), 1594-1601.

Rose, G.M., Shoham, A., Neill, S., \& Ruvio, A. (2007). Manufacturer perceptions of the consequences of task and emotional conflict within domestic channels of distribution. Journal of Business Research, 60 (4), 296-304.

Schneider, W. (1985). Developmental trends in the metamemory-memory behavior relationship: An integrative review. In D.L. Forrest-Pressley, G.E. MacKinnon, \& T.G. Waller (Eds.), Metacognition, cognition, and human performance. Vol. 1 (pp. 57109). New York: Academic.

Sternberg, R. (1998). Metacognition, Abilities, and Developing Expertise: What Makes an Expert Student? Instructional Science, 26, 127-140.

Welch, C., \& Wilkinson, I. (2005). Network perspectives on interfirm conflict: reassessing a critical case in international business. Journal of Business Research, 58 (2), 205-221.

Wood, V.F., \& Bell, P.A. (2008). Predicting interpersonal conflict resolution styles from personality characteristics. Personality and Individual Differences, 45 (2), 126-131.

Yemelianov, Yu.N. (1990). Teoriâ formirovaniâ i praktika soveršenstvovaniâ kommunikativnoj kompetentnosti [Theory of formation and practice of perfection of communicative competence] (Doctor of Sciences dissertation). Leningrad. 